\title{
Oral vaccination of fish - antigen preparations, uptake, and immune induction
}

\author{
Stephen Mutoloki, Hetron Mweemba Munang'andu and Øystein Evensen*
}

Department of Basic Sciences and Aquatic Medicine, Faculty of Veterinary Medicine and Biosciences, Norwegian University of Life Sciences, Oslo, Norway

The oral route offers the most attractive approach of immunization of fish for a number of reasons: the ease of administration of antigens, it is less stressful than parenteral delivery and in principle, it is applicable to small and large sized fish; it also provides a procedure for oral boosting during grow-out periods in cages or ponds. There are, however, not many commercial vaccines available at the moment due to lack of efficacy and challenges associated with production of large quantities of antigens. These are required to stimulate an effective immune response locally and systemically, and need to be protected against degradation before they reach the sites where immune induction occurs. The hostile stomach environment is believed to be particularly important with regard to degradation of antigens in certain species. There is also a poor understanding about the

OPEN ACCESS

Edited by: Jorge Galindo-Villegas, Murcia University, Spain

Reviewed by: Jaime A. Tobar,

Centrovet Ltda, Chile Scott LaPatra, Clear Springs Foods Inc, USA

*Correspondence: Øystein Evensen oystein.evensen@nmbu.no

Specialty section: This article was submitted to Immunotherapies and Vaccines, a section of the journal

Frontiers in Immunology

Received: 19 May 2015 Accepted: 24 September 2015 Published: 19 October 2015

Citation:

Mutoloki S, Munang'andu HM and Evensen $\varnothing$ (2015) Oral vaccination of fish - antigen preparations, uptake, and immune induction.

Front. Immunol. 6:519. doi: 10.3389/fimmu.2015.00519 requirements for proper immune induction following oral administration on one side, and the potential for induction of tolerance on the other. To what extent primary immunization via the oral route will elicit both local and systemic responses is not understood in detail. Furthermore, to what extent parenteral delivery will protect mucosal/gut surfaces and vice-versa is also not fully understood. We review the work that has been done on the subject and discuss it in light of recent advances that include mass production of antigens, including the use of plant systems. Different encapsulation techniques that have been developed in the quest to protect antigens against digestive degradation, as well as to target them for appropriate immune induction are also highlighted.

Keywords: oral vaccination, fishes, oral tolerance, antigen production, local and systemic immune responses

\section{BACKGROUND}

Mucosal surfaces constitute the largest body area of living organisms in constant contact with the external environment and are responsible for the maintenance of immunological homeostasis. The gut is the most attractive route for antigen delivery in fish for several reasons. It offers an easy way of administering antigens; delivery is less stressful, both small and large sized fish can be vaccinated and this approach is associated with no side effects. Despite these advantages, there are currently very few oral vaccines registered for use in the aquaculture industry. For example, out of $17 \mathrm{com}$ mercially available vaccines against viruses reported in 2014, only 2 were oral preparations (1). This low number was attributed to poor performance of oral vaccines in general compared to their injection counterparts (2), possibly as a result of antigen degradation during passage through the hostile stomach environment prior to reaching the second segment of the intestine where absorption 
takes place. Despite this, the search for oral vaccines that meet the desired induction of the immune response and protection has continued. The struggle in developing good oral vaccines is complicated by the lack of proper understanding of what constitutes good immunological induction leading to protection on one side, and the induction of tolerance on the other.

For the most part, efforts to develop vaccines whether for parenteral or oral administration have been largely directed at bacterial and viral infections. Recently, however, other challenges facing the aquaculture industry, namely, ectoparasites have prompted efforts to address in particular sea lice and amoeba infections in salmonids.

\section{ANTIGEN UPTAKE AND DISTRIBUTION}

The gut of teleosts can be subdivided into two groups in terms of the uptake of macromolecules: (1) those devoid of stomachs, i.e., pre-larval stages of fish as well as certain species that do not develop stomachs throughout their life time, e.g., cyprinids; (2) fish with stomachs and therefore possess a segment of low $\mathrm{pH}$ and are capable of pre-digestion (3). The gut can further be divided into three segments based on the morphology of enterocytes namely segment 1: 60-75\% of the total gut length depending on species with cells considered absorptive; segment 2: 10-15\% of the gut length and with enterocytes characterized by large supranuclear vacuoles and high pinocytotic activity; and segment 3: less well-characterized but with enterocytes that have osmoregulatory function and short microvilli [summarized in Ref. $(4,5)$ ].

The most uptake of macromolecules in the gut of fish takes place in the second segment although in a few species like the cod, this segment has not been identified (6). In general, particulate and soluble antigens are taken up by different mechanisms: particles such as horse radish peroxidase (HRP) in carp are thought to be taken up by receptor-mediated endocytosis (7). HRP was observed in the endolysosomal compartment followed by intercellular spaces where after it was observed systemically (8). Ferritin (soluble), on the other hand, was taken up into supranuclear vacuoles (endosomes), a route believed to be used also by other soluble factors such as bacterial LPS (9).

Antigens administered via the gut are invariably taken up by cells lining this organ such as enterocytes and $\mathrm{M}$ cells in the case of higher vertebrates. In fish, enterocytes have been shown to take up antigens $(10,11)$. M-like cells, on the other hand, have been shown to have functional endolysosomal organelles and not able to phagocytoze inactivated bacteria in fish (5). It is nevertheless thought that if aided with certain signals like poly D, L-lactide-coglycolic acid (PLGA) microparticles, M-like cells may still be able to take up antigens (12). It is generally considered that the best immune induction will be that which mimics a natural infection. Different pathogens are internalized by different routes/receptors under natural infections and it is not unlikely that some of the pathogen for which oral vaccines are sought will not reach or target the enterocytes. To what extent this will be an issue in the efficacy of oral vaccines remains to be shown. This is especially relevant given the compartmentalization of immune responses as discussed below. As fish reside in the aquatic environment, it is likely that most pathogens will invade via mucosal routes, including the gills, skin (fin bases) (13), and also via the gut (14-16).

\section{IMMUNE INDUCTION FOLLOWING ORAL VACCINATION}

It is well-known that lymphoid structures associated with the gut of fish are different from those of mammals. Fish do not have lymph nodes or Peyer's patches but instead possess a less organized, diffuse gut-associated lymphoid tissue (GALT), which is functionally different from that of mammals (17). Nevertheless, the fish GALT is capable of local immune responses. Indeed, oral administration of antigens result in the up-regulation of genes related to recruitment of immune cells (18) and local antibody production $(19,20)$. Protection is, however, variable with some reporting adequate $(3,21-23)$ and others inadequate (24). As primary vaccines, orally delivered vaccines especially containing inactivated whole antigens have traditionally not featured well, often resulting in suboptimal protection against several pathogens. When used for boosting, however, oral vaccines have been shown to be capable of enhancing or extending protection (25) although the antibody response is transient, typically lasting about 3 months $(3,9,12,26)$. Interestingly, varying the dosage regime, for example, by administering the vaccine 3 days/week for 2 months instead of 5 days/month gave different results with the former being more effective (24). The basis for this difference has not been examined but may reflect a delicate balance that has to be maintained in augmenting the immune response by oral boosting and should be subject of further studies.

Other factors that influence efficacy of oral vaccines include the nature of antigens, formulation, and dosage. Bacterial whole antigens generally perform better than viral antigens. Formulation is important for some vaccines in general and for oral vaccines, it is even more so given that they act as a means to protect antigens through the stomach as further discussed below.

Dosage is key to any vaccine regime and for orally administered vaccines, it is difficult to determine the dose at individual level. Examination of feed residues and weight gain at population level following feeding gives an idea of the average in-take in the population. Then comes the distribution of antigens per weight unit of feed or per pellet, which is also difficult to determine. This is a topic addressed to a very little extent in published studies and potentially has a great impact on the outcome of mucosal immunization modalities.

Compartmentalization of the immune system is yet another factor to consider, a well-known phenomenon in mammals. The basis for this is the trafficking of immune competent cells aided by homing receptors $(27,28)$. Further to this, whether an asymmetric immune response is induced in fish as seen in mice (29) is not known. If so, the concept would be that immune responses induced in the gut would induce local and systemic immune responses, while parenteral delivery will not yield protective immune responses on mucosal surfaces (Figure 1). In a recent study, it was shown that rainbow trout infected with a gut parasite (Ceratomyxa shasta) had local (gut) IgT responses but not IgM responses, while systemically, IgM levels were high but 


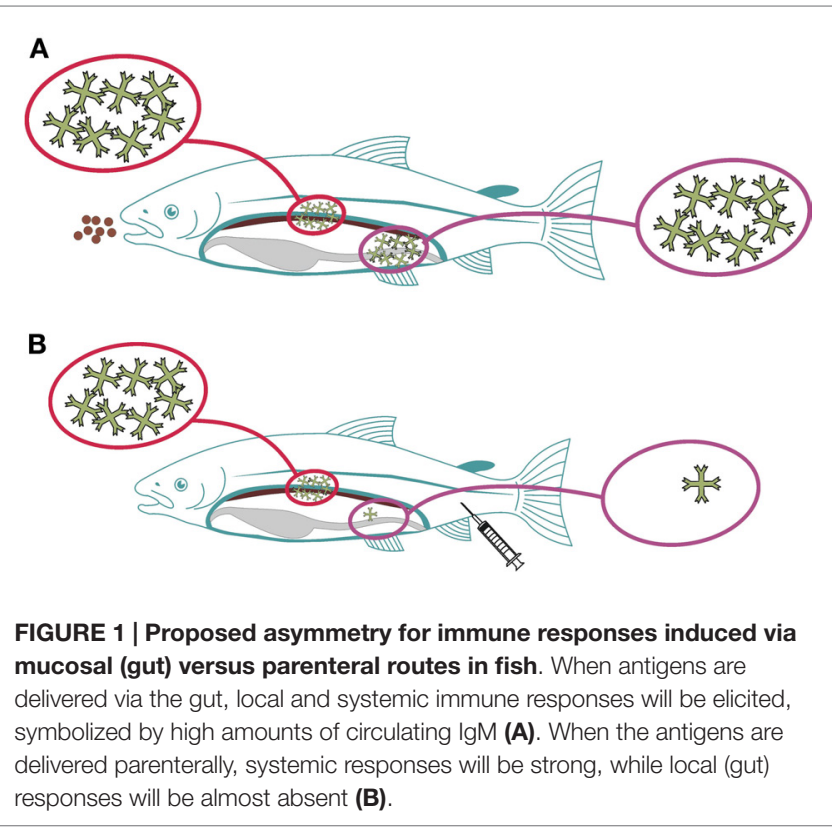

IgT was not detected in circulation (30). Reciprocal modalities were not tested but in a recent study it was shown that parenteral vaccination efficiently stimulates systemic responses but is a poor inducer of mucosal immunity $(12,31)$. Furthermore, oral administration of antigens results in stimulation of both systemic and mucosal responses $(32,33)$. Together, these findings align with a hypothesis also for fish that the immune response shows an asymmetrical pattern but further studies are needed to better understand the importance and implications.

Mucosal immunoglobulins (such as IgT or IgZ) are relative new discoveries in fish immunology. For this reason, their functional role is not well-understood/studied and in general, very few studies (perhaps none) show that IgT plays a role in protecting mucosal surfaces. Although Zhang and co-workers (30) provides some guidance, it does not show that IgT is protective. It could be that IgT merely plays a role in regulating the commensal flora thus keeping it in check, preventing the proliferation of any single bacterial species beyond a level that could potentially result in pathology and disease, in line with current thinking in mammalian immunology (34). There are a few studies on the potential importance of IgT in the gills (intraepithelial location) against $I$. multifilis infection but the functional importance of IgT $+\mathrm{B}$ cells is actually not known (35).

\section{ORAL TOLERANCE}

Oral tolerance is defined as the hypo-responsiveness to a fed antigen (36) and is a result of the suppression of the cellular and/ or humoral immune response (37). It is a phenomenon that has been well-known for ages and in fish, it has been recognized as the suppression of antibodies $(12,24,26)$ and is easily induced. In higher vertebrates, the causes of tolerance are multiple including low doses that favor the induction of Tregs; and higher doses associated with anergy (36). Repeated administration of small amounts of antigens, vaccination of too young (immunocompetent) fish, low temperatures (lower end of the permissive limit), type of antigens and administration regime as well as genetics are factors that have been implicated in the induction of tolerance in fish $(11,18,24,38)$.

Mechanisms of tolerance involve the induction of Tregs associated with up-regulation of FoxP3 and production of TGF$\beta$ (Figure 2). Other cells are also involved and these include dendritic cells, macrophages, and epithelial cells. In fish, the mechanisms have not been elucidated in any detail; it is for the most part illustrated by decreased antibody response following repeated antigen exposure $(24,26,32)$. It is only recently that it has been shown that the suppression of antibody production was accompanied by the induction of FoxP3, TGF- $\beta$, and IL-10 (32), strengthening the belief that the mechanism is comparable to that of higher vertebrates.

\section{RECENT DEVELOPMENTS TO IMPROVE THE PERFORMANCE OF ORAL VACCINES IN FISH}

The disadvantages associated with oral vaccines include their demand for high antigens requirements, the need to protect antigens as they pass through the stomach as well as the formulation of vaccines to improve the stimulation of protective immunity. The following are the strides that have been taken by the scientific community to bring the frontier of oral vaccinology in fish forward.

\section{ANTIGEN PRODUCTION}

A prerequisite to the production of any vaccine is the ability to scale-up antigens easily and at a low cost. While bacteria and bacteria-based products, such as subunit antigens, are quite easily propagated by fermentation, scaling up for virus antigens can be challenging and thus this section focusses mainly on virus antigens.

\section{Virus Antigen Preparation}

Virus antigens used in the production of vaccines in general and oral vaccines in particular range from native whole pathogens (whole virus preparations) to subunit or synthetic products.

\section{Native Whole Pathogen Antigens}

At present, most commercial vaccines against viral diseases for parenteral delivery in fish are produced by inactivating whole pathogens. For fish vaccines, viral antigens are typically produced by propagation in cell culture and this is limited by the yield obtained. As an example, infectious pancreatic necrosis virus (IPNV) produces yields ranging between $10^{6}$ and $10^{10} \mathrm{TCID}_{50} \mathrm{ml}^{-1}$ if grown in RTG 2, CHSE, or other permissible cell lines (39-41). This is complicated by the fact that yields may be inconsistent and differ greatly between workers and laboratories. To resolve the problems stated above, several solutions have been attempted in recent years, including (1) discovery of cell lines with short regeneration time and high antigen yields; and (2) development of cell culture systems that can house higher cell numbers per 


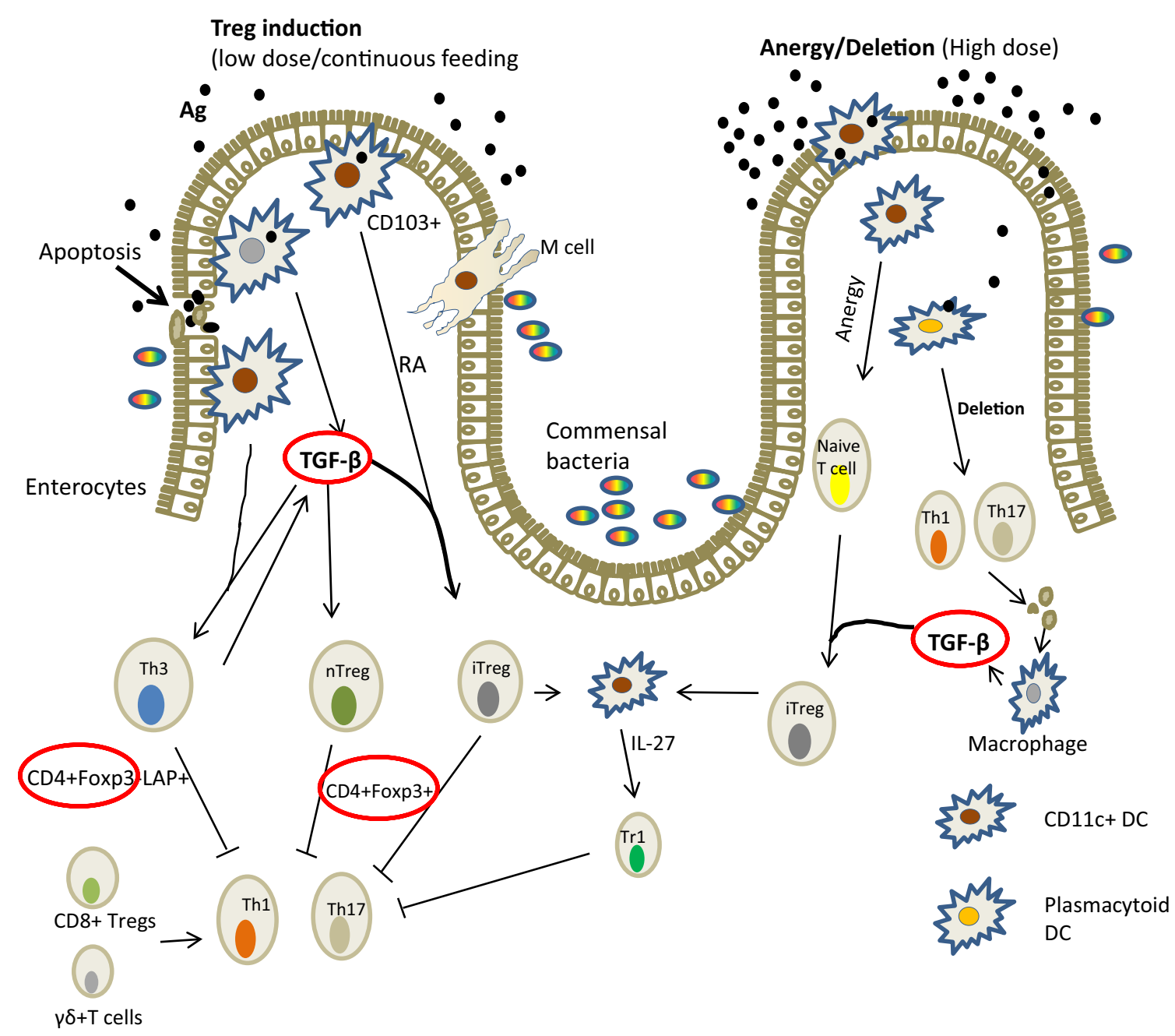

FIGURE 2 | Mechanism of induction of oral tolerance in the gut in mammals [adapted from Ref. (36)]. There are several ways in which oral antigens may be taken up through the gut epithelium: by the enterocytes; sampled by DCs (macrophage-like cells in fish) that penetrate the lumen or via M cells. The gut environment favors tolerance probably to allow for gut microflora. DCs are known to drive Treg differentiation from FoxP3, TGF- $\beta$, and IL-10 from gut epithelial cells. Lower antigen doses tend to induce TGF- $\beta$ while high doses lead to anergy. In Atlantic salmon, the expression of IL-10, TGF- $\beta$, Foxp3 (circled red) associated with suppressed antibody responses have been demonstrated (32). Key: TGF, transforming growth factor; RA, retinoic acid; DC, dendritic cells; LAP, latency associated peptide; Foxp3, forkhead box protein; IL, interleukin.

unit volume. Using IPNV as an example, Asian Grouper strain $\mathrm{K}$ cells (AGK cells) have been produced from the skin of Orange spotted grouper (Epinephelus coioides) that yield high amounts of virus (approximately $10^{10} \mathrm{TCID}_{50} \mathrm{ml}^{-1}$ ) (42) while having a short cell-generation turn-around time, i.e., frequent splits and high split ratios (43).

For cell culture systems, flasks that can accommodate more cells per unit volume than ordinary flasks have recently been developed by commercial companies. An example is the multilayered hyper flasks from Corning ${ }^{\circledR}$ with scaled-up volume (up to 10 times) on which cells can be grown (www.sigmaaldrich.com). Another example is the BelloCell ${ }^{\circledR}$ from CESCO Bioengineering Inc. (44). The principle of the BelloCell is that of alternating nutrient and gaseous exchange. This results in maximum cell growth and increased cell population. Indeed, improved cell growth has been reported using this method and it has potential for use in fish vaccination, although currently there are no reports that suggest that it has yet been used so far. Other developments include the three dimensional cell culture systems, such as Hydromatrix ${ }^{\mathrm{TM}}$, MaxGel ${ }^{\mathrm{TM}}$, and Mouse ECM from Sigma ${ }^{\circledR}$ that mimic in vivo growth conditions of cells. As with BelloCells, the systems result in better growth of cells and will likely lead to increased antigen yields. Finally, the contribution of other improvements in the cell culture cultivation process, for example, refinement in the culture media production and process control cannot be underestimated.

\section{Subunit Antigens Produced in Bacteria and Yeast Cell Systems}

Subunit antigens are produced from heterologous protein expression systems and offer the safest and most attractive means of antigen production. Unlike live pathogens or DNA vaccines, 
subunit vaccines do not pose the risk of invading the host or integrating with the host DNA. In fish vaccinology, the most widely used protein expression systems for the production of subunit antigens are E. coli and yeast. Commercial oral vaccines have been used previously or are in production on the basis of these techniques (45-47). Nevertheless, other systems for example the Baculovirus expression system in eukaryotic cells has also been used especially at experimental level (33).

\section{Subunit Antigens in Plant-Based Systems}

During the last decade, the use of whole plants as antigen production systems has received a lot of attention owing to the advantages that they offer, such as ease of scaling up, reduced costs, and good safety margins (48). These systems have also been referred to as molecular farming and are the utilization of whole plants or plant cells/tissues cultured in vitro for the production of recombinant proteins. Plants have advantages compared to traditional platforms of recombinant protein production in the sense that they are less expensive to establish and maintain, they lack undesirable components such as hyper glycosylated proteins as found in yeast, and extraneous agents are less of a problem. Scalability is relatively easy. Finally, plants are higher eukaryotes and can fold and assemble complex/multimeric proteins and also perform post-translational modifications (48). Despite these many advantages, there are currently no recombinant proteins produced commercially. Many proofof-principle studies have been done and several companies are investigating and exploring the commercial feasibility of such production systems. The focus of such efforts has been directed at a small number of well-characterized plants of which Tobacco cultivars Bright Yellow (BY-2) and Nicotiana tabacum 1 (NT-1) are most popular (49). It is noteworthy, however, that plant systems lack intrinsic benefits of cultured cells, for example, the difficulty associated with the control of growth conditions and batch to batch inconsistency (49). Regardless, this is likely to be the trend for the future also for the aquaculture research community (48).

\section{DNA-Based Antigens}

DNA-based vaccines in the aquaculture industry have met some success with one injectable vaccine against infectious hematopoietic necrosis in Atlantic salmon being licensed for commercial use in Canada (50). Although there is no commercial vaccine yet licensed for use as an oral vaccine, induction of protection against IPNV has been reported using this method at experimental level (21). The biggest problem with DNA vaccines in the aquaculture industry at the moment is the licensing requirements related to integration into genome studies, in principle related to safety to the end-consumer more than the vaccinated animal $(51,52)$.

\section{Bacterial Antigens}

In general, there has been more success with bacterial vaccines of the aquatic industry compared to their viral counterparts, for example, if we look at the relative number of commercial vaccines for salmonids in Norway (53). There are several reason for this, while all viruses are intracellular pathogens, most of the bacteria important to the fish industry are extracellular, with only a few exceptions for example Piscirickettsia salmonis whose vaccine development has equally been a challenge (54). The effective immunological response against extracellular bacterial pathogens is predominantly humoral, thus vaccines that act by inducing antibody responses will normally suffice to protect the animals against challenge. By contrast, protection against intracellular pathogens requires a combination of immunological responses, including humoral, cell-mediated, and cytotoxic responses. To produce a vaccine which induces all these responses is what makes it a challenge. By contrast, factors that contribute to the relative ease in development of bacterial vaccines compared to viral vaccines are their relatively large size and the type of antigens/immunogens they possess.

Oral bacterial vaccines have similar challenges as viral vaccines, for example, degradation of antigens as they pass through the stomach and requirements for large volumes. A study by Villumsen and others showed that protection of fish was conferred if the vaccine was administered anally compared to the oral route, with the authors suggesting that orally fed antigens were digested in the stomach (55). Indeed, commercial bacterial vaccines for oral administration, e.g., enteric red mouth vaccine (Aquavac ERM Oral vet from MSD animal health) are only intended for use as booster vaccines (56). Consequently, several studies aimed at finding the best solution to protect bacterial antigens in the stomach of fish have been conducted (57) and these are discussed in the sections below.

Some bacteria, specifically Lactobacillus expressing various proteins of IPNV have been applied in studies of oral vaccination of fish $(58,59)$. Although the results are contrasting, this is nevertheless an interesting concept that warrants further follow-up, as does the delivery of a combination of bacteria and viruses as multivalent oral vaccines. This may help synergize responses to viral antigens as has been observed for injectable vaccines.

\section{ENCAPSULATION TECHNIQUES}

Encapsulation refers to incorporation of materials, including food ingredients, cells, or others, into small capsules and is accomplished by several different techniques (60). Encapsulated materials, e.g., vaccine antigens can then be mixed with food for oral administration. In vaccine development for fish, there are essentially three methods by which this is done: (1) finished feed is top-dressed with vaccine powder by using adhesive agents, e.g., edible oil or gelatin; (2) finished feed is sprayed with the vaccine if the latter is in liquid form; and (3) mixing the antigen with the feed in the production process (61). The first two methods (top dressing) are quite simple to apply but have the disadvantage of uneven distribution in the feed and also the threat that the antigens are directly exposed to hostile stomach environment upon feeding, leading to degradation. By contrast, mixing the antigen with the feed gives the advantage of uniform distribution of the antigens in the feed. Since most fish feed is produced through an extrusion process at high temperature and pressure antigens would have to be added to the pellet at later stages, either in a vacuum infusion coating process. As a means of protecting 
the antigens against the hostile stomach environment, several encapsulations techniques have been developed and tried as discussed below.

\section{Microalgae}

Microalgae are potentially future candidates of recombinant vaccine production (62) both for higher vertebrates and the fish industry. This system is said to have among other advantages the ease of scalability, rapid transformation, and consistent transgene expression levels (62). In oral vaccination of fish, however, there are no reports on the use of this technology.

\section{Alginate Particles}

Alginates are another carrier that promises to revolutionize oral vaccine development. They occur naturally in brown algae and have been targets for trapping macromolecules and cells (63). In the aquaculture industry, they have been tested quite extensively (Table 1).

As can be seen from the table above, alginates seem to work well with DNA plasmids, giving RPS values of $67 \%$ or more in all species tested. Whether this technology can be transferred to other viral diseases of fish would be interesting.

\section{Nanoparticles}

In recent years, increased knowledge has accumulated over the use of different forms of nanoparticles in oral vaccination of fish. Rajesh et al. (71) examined the use of chitosan nanoparticles for orally delivering a DNA vaccine against Vibrio anguillarum in sea bass. While they demonstrated that fish took up the antigens, fish were, however, not protected and a relative RPS rate of $46 \%$ was recorded. A better protection against $V$. parahaemolyticus was recorded in black seabream (Acanthropagus schelegelii Bleeker) also vaccinated with a DNA vaccine loaded in nanoparticles, resulting in $72.3 \%$ RPS 3 weeks post vaccination.

For viral diseases, encapsulating DNA vaccines against infectious hematopoietic necrosis virus with Poly (D,L-lactic-Coglycolic acid) (PLGA) nanoparticles and adding to feed pellets showed that rainbow trout took-up the vaccine in the lower intestine within $96 \mathrm{~h}$ of feeding and also induced low levels of gene expression and specific antibodies but this was not sufficient to protect the fish against lethal challenge (72). When a DNA vaccine against lymphocystis loaded in PLGA was used to feed Japanese flounder, several innate immune parameters were induced suggesting that the system could be used as a carrier for plasmid DNA vaccines (73). Recently, Rivas-Aravena and coworkers (74) reported enhanced protection of Atlantic salmon fed with chitosan nanoparticles-based oral vaccines loaded with a DNA coding an alphavirus replicase (as an adjuvant) while the target antigen was ISAV. The authors reported $77 \%$ protection.

\section{Biofilms}

Biofilms are defined as communities of microbes adherent on a surface and usually held together by a polymetric extracellular matrix $(75,76)$. In so doing, they form a protective coat which has been taken advantage of in vaccine studies of fish to prevent the degradation of antigens through the stomach. Work in fish vaccination using biofilms is not as extensive as literature dates
TABLE 1 | Summary of previous studies of oral vaccination of fish using alginate microparticles.

\begin{tabular}{|c|c|c|c|}
\hline Target & $\begin{array}{l}\text { Fish } \\
\text { species }\end{array}$ & Result & Reference \\
\hline $\begin{array}{l}\text { Commercial } \\
\text { Vibrio anguillarum } \\
\text { vaccine in two }\end{array}$ & $\begin{array}{l}\text { Carp and } \\
\text { rainbow } \\
\text { trout }\end{array}$ & $\begin{array}{l}\text { Antibodies produced by carp } \\
\text { only; protection not assessed }\end{array}$ & (38) \\
\hline
\end{tabular}

types of alginate

microspheres

Plasmid DNA

expressing major

capsid protein of

lymphocystis disease

virus

Aeromonas

salmonicida

recombinant A layer

proteins in alginate

beads

Lactococcus

garvieae bacterin

L. garvieae bacterin

Japanese Antigens detected in various

flounder tissues between 10 and

90 days post immunization

(64)

Goldfish Antibodies produced but no difference in disease susceptibility between the control and treatment groups after challenge

\section{Rainbow \\ trout}

RPS of 50 achieved

Rainbow Achieved RPS of 53 after 30 days following challenge; after a boost at 61 days, RPS increased to 61 at 120 days
Flavobacterium

columnare

bacterium in alginate

microparticles;

compared oral and

parenteral deliveries

Infectious pancreatic necrosis virus VP2 plasmid DNA in

alginate microspheres; trout

administered by

intubation

IPNV VP2 plasmid DNA in feed pellets

Inactivated IPNV virus encapsulated in alginate beads; feed pellets

\section{Nile No protection or significant tilapia antibody production in oral group}

Brown RPS of 84 (brown trout) and trout and between 67 and 83 (rainbow rainbow trout) after 30 days back to 2000-2004 and was centered on A. hydrophila $(2,77)$. In general, all the studies reported significant protection of fish fed with biofilms compared to free cells. No additional work has been reported thereafter.

\section{Artemia}

First described in the mid 1700s by Schlosser, Artemia have gained value as food for fish as well as for other uses (78). Artemia naturally consume the bacteria that they are immersed with thereby readily encapsulating them and it is this property that is exploited in vaccine development. This approach has been examined in oral vaccination of fish targeting different bacteria not only $V$. anguillarum (38) but also recombinant $E$. coli. (46). Where the immune response was evaluated, there were indications of immunosuppression following very early vaccination in carp while an increased antibody response was 
reported for older carp immunized at 58 days. Similarly, older sea bream developed highly increased antibodies 21 days following a boost (38).

\section{Oral Vaccines Against Sea Lice and Amoeba}

As fish farming expands, so does the number of important ectoparasites (79). In the salmonid industry at present, the most important ectoparasites include sea lice (Lepeophtheirus salmonis and Caligus rogercrossey) and amoeba (Neoparamoeba perurans) the causative agents of amoebic gill disease. Conventional treatments against the former have mainly involved the use of chemotherapy with products, such as organophosphates (80) and avermectins (81) but as with many other drugs, resistance is an increasing problem $(82,83)$. Amoebic gill disease is more problematic to treat but repeated freshwater baths (84) and also hydrogen peroxide (85) are used.

When it comes to vaccination, to the knowledge of the authors, there are no reports that address oral vaccination against sea lice (L. salmonis) in Atlantic salmon, or (C. rogercrossey) in Coho salmon. Since both parasites attach to and complete their life cycle on the skin of salmon, it is assumed that local responses would be important in preventing infections but so far no attempts have been made to induce immune responses via the mucosa.

Similarly, there are apparently no records on testing oral vaccines against amoeba in fish. Interestingly, in rodents, Yersinia enterocolitica expressing an amoeboid outer protein as a fusion protein has been shown to induce some degree of protection (86, 87). This could be an avenue to explore also for fish as an antigen delivery model against amoeba.

\section{Summary of Status and Future Directions}

There is a consensus among scientists working in this field that antigen uptake in teleosts takes place in the second gut segment. In order for some antigens to reach this site, protection against degradation in the stomach is necessary. The second gut segment is possibly the site where immune induction is initiated locally for antigens taken up from the intestines. However, the cell types, molecular elements, and even immune organs involved are yet to be definitively elucidated. Central to this is the role of IgT or IgZ, for example, do they neutralize antigens or merely regulate the relative number of bacteria in the gut microbiome? Could it be that bacteria coated with IgT represent proliferating, potentially disease-causing bacteria? Furthermore, what roles do IgT or IgZ have vis-à-vis IgM in protective immunity? What functional significance does compartmentalization of the different isotypes have? Thus, the mechanism of immune induction (local and systemic) and protection following oral vaccination is yet to be elucidated. Reagents that allow functional studies of IgT are in very few hands at the moment, and this has partly caused the slow pace in understanding its role in the protection of fish against pathogens. Further, it will be important to understand if antigens delivered at mucosal surfaces (oral, skin, gills, and/or nasal) will elicit both local and systemic responses. Studies here are not conclusive. While IHN virus delivered nasally elicit systemic immune responses (88) it has also been shown that live and inactivated IPN virus are taken up when delivered orally and anally (10). IPNV delivered orally give a boost response to circulating IgM (10). Despite these findings, there is a need to better understand if inactivated and live (replicating) antigens differ in their ability to induce systemic, protective responses when antigens are delivered locally. The potential of differences between pathogens also need to be explored.

When it comes to vaccine formulation, several candidates that can serve as vehicles for antigens, for example, alginates have been identified and shown to be capable of protecting antigens against degradation in the stomach. The contribution of these vehicles toward augmentation of the immune response, however, remains poorly understood. Similarly, the effects of adjuvants in this field have not been well explored, except for a few studies, e.g., recombinant TNFa (89). This is an area that is likely to take focus, as shall the continued exploration of more effective encapsulation techniques.

In terms of antigen preparations, a number of products are commercially available on the market that makes it easier and cheaper to produce larger volumes of antigens, especially those of virus nature. Here, the use of plants gives an interesting impetus and need following up.

Finally, when it comes to DNA vaccines, the future is not easy to predict. There is no doubt that progress will continue for injectable vaccines especially where other approaches have little or no efficacy. For oral vaccines as well, DNA preparations will come. However, acceptability in some regions such as Europe will depend on changes in legislation (90).

\section{CONCLUSION}

The last decade has seen an increase in the number of studies addressing oral vaccination of fish. The discovery of new methods of efficiently producing antigens particularly of viral antigens and the concept of using plant systems for the production of recombinant antigen presents new exciting future possibilities. Unraveling the immune response to antigens in the oral compartment and systemically vis-à-vis oral tolerance remains a challenge and requires more efforts. Finally, there is need to understand better a potential asymmetry in the immune responses of fish elicited by antigens delivered via the gut (or mucosal surfaces in general) versus parenteral delivery of antigens, and the importance of this for protecting the primary barriers of infection.

\section{ACKNOWLEDGMENTS}

Work leading to preparation of this paper was funded by the TARGETFISH, Targeted Disease Prophylaxis in European Fish Farming, EU Grant 311993. "Nanoparticle encapsulation of plant-based vaccine against piscine reovirus infection in salmon" RCN grant no. 239140, and "Sea Lice Research Centre", RCN grant no. 203513. We acknowledge the assistance from Dr. Ida Skaar, Norwegian Veterinary Institute, Oslo, Norway in preparing Figure 1. 


\section{REFERENCES}

1. Dhar AK, Manna SK, Thomas Allnutt FC. Viral vaccines for farmed finfish. Virusdisease (2014) 25(1):1-17.

2. Quentel C, Vigneulle M. Antigen uptake and immune responses after oral vaccination. Dev Biol Stand (1997) 90:69-78.

3. Stroband HW, van der Meer JH, immermans LPM. Regional functional differentiation in the gut of the grasscarp, Ctenopharyngodon idella (Val.). Histochemistry (1979) 64:235-49. doi:10.1007/BF00495024

4. Rombout JHWM, Bot HE, Taverne-Thiele JJ. Immunological importance of the second gut segment of carp. J Fish biol (1989) 35(2):167-78. doi:10.111 1/j.1095-8649.1989.tb02966.x

5. Rombout JHWM, Yang G, Kiron V. Adaptive immune responses at mucosal surfaces of teleost fish. Fish Shellfish Immunol (2014) 40(2):634-43. doi:10.1016/j.fsi.2014.08.020

6. Inami $\mathrm{M}$, Taverne-Thiele $\mathrm{AJ}$, Schrøder MB, Kiron $\mathrm{V}$, Rombout JHWM. Immunological differences in intestine and rectum of Atlantic cod (Gadus morhua L.). Fish Shellfish Immunol (2009) 26(5):751-9. doi:10.1016/j. fsi.2009.03.007

7. Rombout JH, Lamers CH, Helfrich MH, Dekker A, Taverne-Thiele JJ. Uptake and transport of intact macromolecules in the intestinal epithelium of carp (Cyprinus carpio L.) and the possible immunological implications. Cell Tissue Res (1985) 239(3):519-30. doi:10.1007/BF00219230

8. McLean E, Ash R. The time-course of appearance and net accumulation of horseradish peroxidase (HRP) presented orally to juvenile carp Cyprinus carpio (L.). Comp Biochem Physiol A Comp Physiol (1986) 84(4):687-90. doi:10.1016/0300-9629(86)90388-9

9. Tatner MF, Horne MT. Susceptibility and immunity to Vibrio anguillarum in post-hatching rainbow trout fry, Salmo gairdneri Richardson 1836. Dev Comp Immunol (1983) 7(3):465-72. doi:10.1016/0145-305X(83)90031-9

10. Chen L, Evensen $\varnothing$, Mutoloki S. IPNV antigen uptake and distribution in Atlantic salmon following oral administration. Viruses (2015) 7(5):2507-17. doi:10.3390/v7052507

11. Joosten PH, Engelsma MY, van der Zee MD, Rombout JH. Induction of oral tolerance in carp (Cyprinus carpio L.) after feeding protein antigens. Vet Immunol Immunopathol (1997) 60(1-2):187-96. doi:10.1016/S0165-2427(97)00124-4

12. Firdaus-Nawi M, Zamri-Saad M, Nik-Haiha NY, Zuki MA, Effendy AW. Histological assessments of intestinal immuno-morphology of tiger grouper juvenile, Epinephelus fuscoguttatus. Springerplus (2013) 2:611. doi:10.1186/2193-1801-2-611

13. Harmache A, LeBerre M, Droineau S, Giovannini $M$, Bremont $M$. Bioluminescence imaging of live infected salmonids reveals that the fin bases are the major portal of entry for Novirhabdovirus. J Virol (2006) 80(7):3655-9. doi:10.1128/JVI.80.7.3655-3659.2006

14. Birkbeck TH, Ringø E. Pathogenesis and the GI tract of growing fish. In: Holzapfel W, Naughton P, editors. Microbial Ecology of the Growing Animal. Amsterdam: Elsevier (2004). p. 208-34.

15. Ling SH, Wang XH, Lim TM, Leung KY. Green fluorescent protein-tagged Edwardsiella tarda reveals portal of entry in fish. FEMS Microbiol Lett (2001) 194(2):239-43. doi:10.1111/j.1574-6968.2001.tb09476.x

16. Sakai DK. Invasive routes of Aeromonas salmonicida subsp. salmonicida. Sci Rep Hokkaido Salmon Hatchery (1979) 34(61):89.

17. Rombout JH, Abelli L, Picchietti S, Scapigliati G, Kiron V. Teleost intestinal immunology. Fish Shellfish Immunol (2011) 31(5):616-26. doi:10.1016/j. fsi.2010.09.001

18. Rombout JHWM, Kiron V. Mucosal vaccination of fish. In: Gudding R, Lillehaug A, Evensen O, editors. Fish Vaccination. Oxford: Willey Blackwell (2014). p. 56-67.

19. Anuradha K, Foo HL, Mariana NS, Loh TC, Yusoff K, Hassan MD, et al. Live recombinant Lactococcus lactis vaccine expressing aerolysin genes D1 and D4 for protection against Aeromonas hydrophila in tilapia (Oreochromis niloticus). J Appl Microbiol (2010) 109(5):1632-42. doi:10.1111/j.1365-2672.2010.04789.x

20. Siriyappagouder P, Shankar KM, Naveen Kumar BT, Patil R, Byadgi OV. Evaluation of biofilm of Aeromonas hydrophila for oral vaccination of Channa striatus. Fish Shellfish Immunol (2014) 41(2):581-5. doi:10.1016/j. fsi.2014.09.021

21. Li L, Lin SL, Deng L, Liu ZG. Potential use of chitosan nanoparticles for oral delivery of DNA vaccine in black seabream Acanthopagrus schlegelii Bleeker to protect from Vibrio parahaemolyticus. J Fish Dis (2013) 36(12):987-95 doi:10.1111/jfd.12032

22. Pabst R, Russell MW, Brandtzaeg P. Tissue distribution of lymphocytes and plasma cells and the role of the gut. Trends Immunol (2008) 29(5):206-8. doi:10.1016/j.it.2008.02.006

23. Tobar JA, Jerez S, Caruffo M, Bravo C, Contreras F, Bucarey SA, et al. Oral vaccination of Atlantic salmon (Salmo salar) against salmonid rickettsial septicaemia. Vaccine (2011) 29(12):2336-40. doi:10.1016/j. vaccine.2010.12.107

24. Maurice S, Nussinovitch AF, Jaffe NF, Shoseyov OF, Gertler A. Oral immunization of Carassius auratus with modified recombinant a-layer proteins entrapped in alginate beads. Vaccine (2004) 23:450-9. doi:10.1016/j. vaccine.2004.06.022

25. Ballesteros NA, Rodriguez Saint-Jean S, Perez-Prieto SI. Food pellets as an effective delivery method for a DNA vaccine against infectious pancreatic necrosis virus in rainbow trout (Oncorhynchus mykiss, Walbaum). Fish Shellfish Immunol (2014) 37(2):220-8. doi:10.1016/j.fsi.2014.02.003

26. Rombout JHWM, van den Berg AA, van den Berg CTGA, Witte P, Egberts E. Immunological importance of the second gut segment of carp. III. Systemic and/or mucosal immune responses after immunization with soluble or particulate antigen. J Fish Biol (1989) 35(2):179-86. doi:10.1111/j.1095-8649.1989. tb02967.x

27. Brandtzaeg P, Kiyono H, Pabst R, Russell MW. Terminology: nomenclature of mucosa-associated lymphoid tissue. Mucosal Immunol (2008) 1(1):31-7. doi:10.1038/mi.2007.9

28. Brandtzaeg P, Pabst R. Let's go mucosal: communication on slippery ground. Trends Immunol (2004) 25(11):570-7. doi:10.1016/j.it.2004.09.005

29. Belyakov IM, Derby MA, Ahlers JD, Kelsall BL, Earl P, Moss B, et al. Mucosal immunization with HIV-1 peptide vaccine induces mucosal and systemic cytotoxic $\mathrm{T}$ lymphocytes and protective immunity in mice against intrarectal recombinant HIV-vaccinia challenge. Proc Natl Acad Sci U S A (1998) 95(4):1709-14. doi:10.1073/pnas.95.4.1709

30. Zhang YA, Salinas I, Li J, Parra D, Bjork S, Xu Z, et al. IgT, a primitive immunoglobulin class specialized in mucosal immunity. Nat Immunol (2010) 11(9):827-35. doi:10.1038/ni.1913

31. Valdenegro-Vega VA, Crosbie P, Vincent B, Cain KD, Nowak BF. Effect of immunization route on mucosal and systemic immune response in Atlantic salmon (Salmo salar). Vet Immunol Immunopathol (2013) 151(1-2):113-23. doi:10.1016/j.vetimm.2012.10.010

32. Chen L, Klaric G, Wadsworth S, Jayasinghe S, Kuo TY, Evensen O, et al. Augmentation of the antibody response of Atlantic salmon by oral administration of alginate-encapsulated IPNV antigens. PLoS One (2014) 9(10):e109337. doi:10.1371/journal.pone.0109337

33. Xue R, Liu L, Cao G, Xu S, Li J, Zou Y, et al. Oral vaccination of BacFish-vp6 against grass carp reovirus evoking antibody response in grass carp. Fish Shellfish Immunol (2013) 34(1):348-55. doi:10.1016/j.fsi.2012.11.024

34. Macpherson AJ, Koller Y, McCoy KD. The bilateral responsiveness between intestinal microbes and IgA. Trends Immunol (2015) 36:460-70. doi:10.1016/j. it.2015.06.006

35. von Gersdorff JL, Heinecke RD, Skjodt K, Rasmussen KJ, Buchmann K. Experimental evidence for direct in situ binding of IgM and IgT to early trophonts of Ichthyophthirius multifiliis (Fouquet) in the gills of rainbow trout, Oncorhynchus mykiss (Walbaum). J Fish Dis (2011) 34(10):749-55. doi:10.1111/j.1365-2761.2011.01291.x

36. Weiner HL, da Cunha AP, Quintana F, Wu H. Oral tolerance. Immunol Rev (2011) 241:241-59. doi:10.1111/j.1600-065X.2011.01017.x

37. Weiner HL. Oral tolerance: immune mechanisms and the generation of Th3type TGF-beta-secreting regulatory cells. Microbes Infect (2001) 3(11):947-54. doi:10.1016/S1286-4579(01)01456-3

38. Joosten PHM, Avilés-Trigueros M, Sorgeloos P, Rombout JHWM. Oral vaccination of juvenile carp (Cyprinus carpio) and gilthead seabream (Sparus aurata) with bioencapsulated Vibrio anguillarum bacterin. Fish Shellfish Immunol (1995) 5(4):289-99. doi:10.1006/fsim.1995.0028

39. Lannan CN, Winton JR, Fryer JL. Fish cell lines: establishment and characterization of nine cell lines from salmonids. In vitro (1984) 20(9):671-6. doi:10.1007/BF02618871

40. Munang'andu HM, Fredriksen BN, Mutoloki S, Brudeseth B, Kuo TY, Marjara IS, et al. Comparison of vaccine efficacy for different antigen delivery systems 
for infectious pancreatic necrosis virus vaccines in Atlantic salmon (Salmo salar L.) in a cohabitation challenge model. Vaccine (2012) 30(27):4007-16. doi:10.1016/j.vaccine.2012.04.039

41. Skjesol A, Aamo T, Hegseth MN, Robertsen B, Jorgensen JB. The interplay between infectious pancreatic necrosis virus (IPNV) and the IFN system: IFN signaling is inhibited by IPNV infection. Virus Res (2009) 143(1):53-60. doi:10.1016/j.virusres.2009.03.004

42. Munang'andu HM, Fredriksen BN, Mutoloki S, Dalmo RA, Evensen O. Antigen dose and humoral immune response correspond with protection for inactivated infectious pancreatic necrosis virus vaccines in Atlantic salmon (Salmo salar L). Vet Res (2013) 44(1):7. doi:10.1186/1297-9716-44-7

43. Chen L, Evensen O, Mutoloki S. Delayed protein shut down and cytopathic changes lead to high yields of infectious pancreatic necrosis virus cultured in Asian grouper cells. J Virol Methods (2014) 195:228-35. doi:10.1016/j. jviromet.2013.10.020

44. Lu JT, Chung YC, Chan ZR, Hu YC. A novel oscillating bioreactor bellocell: implications for insect cell culture and recombinant protein production. Biotechnol Lett (2005) 27(15):1059-65. doi:10.1007/s10529-005-8450-3

45. Christie KE. Immunization with viral antigens: infectious pancreatic necrosis. Dev Biol Stand (1997) 90:191-9.

46. Lin JH, Yu CC, Lin CC, Yang HL. An oral delivery system for recombinant subunit vaccine to fish. Dev Biol (Basel) (2005) 121:175-80.

47. Tamaru Y, Ohtsuka M, Kato K, Manabe S, Kuroda K, Sanada M, et al. Application of the arming system for the expression of the 380R antigen from red sea bream iridovirus (RSIV) on the surface of yeast cells: a first step for the development of an oral vaccine. Biotechnol Prog (2006) 22(4):949-53. doi:10.1021/bp060130x

48. Clarke JL, Waheed MT, Lossl AG, Martinussen I, Daniell H. How can plant genetic engineering contribute to cost-effective fish vaccine development for promoting sustainable aquaculture? Plant Mol Biol (2013) 83(1-2):33-40. doi:10.1007/s11103-013-0081-9

49. Hellwig S, Drossard J, Twyman RM, Fischer R. Plant cell cultures for the production of recombinant proteins. Nat Biotechnol (2004) 22(11):1415-22. doi:10.1038/nbt1027

50. Salonius K, Simard N, Harland R, Ulmer JB. The road to licensure of a DNA vaccine. Curr Opin Investig Drugs (2007) 8(8):635-41.

51. Evensen $\varnothing$. Future of fish vaccinology. In: Gudding R, Lillehaug A, Evensen O editors. Fish Vaccination. Oxford: Wiley Blackwell (2014). p. 162-71.

52. Evensen O, Leong JA. DNA vaccines against viral diseases of farmed fish. Fish Shellfish Immunol (2013) 35(6):1751-8. doi:10.1016/j.fsi.2013.10.021

53. Pharmaq AS. Pharmaq - Products. (2015). Available from http://www.pharmaq.no/products/

54. Sommerset I, Krossoy B, Biering E, Frost P. Vaccines for fish in aquaculture. Expert Rev Vaccines (2005) 4(1):89-101. doi:10.1586/14760584.4.1.89

55. Villumsen KR, Neumann L, Ohtani M, Strom HK, Raida MK. Oral and anal vaccination confers full protection against enteric Redmouth disease (ERM) in rainbow trout. PLoS One (2014) 9(4):e93845. doi:10.1371/journal.pone.0093845

56. Lillehaug A. Vaccination strategies and procedures. In: Gudding R, Lillehaug A, Evensen O, editors. Fish Vaccination. Oxford: Willey Blackwell (2014). p. $140-52$.

57. Plant KP, Lapatra SE. Advances in fish vaccine delivery. Dev Comp Immunol (2011) 35(12):1256-62. doi:10.1016/j.dci.2011.03.007

58. Min L, Li-Li Z, Jun-Wei G, Xin-Yuan Q, Yi-Jing L, Di-Qiu L. Immunogenicity of Lactobacillus-expressing VP2 and VP3 of the infectious pancreatic necrosis virus (IPNV) in rainbow trout. Fish Shellfish Immunol (2012) 32(1):196-203. doi:10.1016/j.fsi.2011.11.015

59. Zhao LL, Liu M, Ge JW, Qiao XY, Li YJ, Liu DQ. Expression of infectious pancreatic necrosis virus (IPNV) VP2-VP3 fusion protein in Lactobacillus casei and immunogenicity in rainbow trouts. Vaccine (2012) 30(10):1823-9. doi:10.1016/j.vaccine.2011.12.132

60. Gibbs BF, KermashaS, Alli I, Mulligan CN. Encapsulation in the food industry: a review. Int J Food Sci Nutr (1999) 50(3):213-24. doi:10.1080/096374899101256

61. Komar C, Enright WJ, Grisez L, Tan Z. Understanding fish vaccination. Aqua Culture Asia Pacific Magazine (2004). p. 27-9.

62. Specht EA, Mayfield SP. Algae-based oral recombinant vaccines. Front Microbiol (2014) 5:60. doi:10.3389/fmicb.2014.00060

63. Chan L, Lee H, Heng P. Production of alginate microspheres by internal gelation using an emulsification method. Int J Pharm (2002) 242(1-2):259-62. doi:10.1016/S0378-5173(02)00170-9
64. Tian JY, Sun XQ, Chen XG. Formation and oral administration of alginate microspheres loaded with pDNA coding for lymphocystis disease virus (LCDV) to Japanese flounder. Fish Shellfish Immunol (2008) 24(5):592-9. doi:10.1016/j.fsi.2008.01.009

65. Romalde JL, Luzardo-Alvarez A, Ravelo C, Toranzo AE, Blanco-Wendez J. Oral immunization using alginate microparticles as a useful strategy for booster vaccination against fish lactoccocosis. Aquaculture (2004) 236(1-4):119-29. doi:10.1016/j.aquaculture.2004.02.028

66. Altun S, Kubilay A, Ekici S, Didinen BI, Diler O. Oral vaccination against Lactococcosis in rainbow trout (Oncorhynchus mykiss) using sodium alginate and poly (lactide-co-glycolide) carrier. Kafkas Univ. Vet. Fak Derg. (2010) 16(B):211-7.

67. Leal CAG, Carvalho-Castro GA, Sacchetin PSC, Lopes CO, Moraes AM, Figueiredo HCP. Oral and parenteral vaccines against Flavobacterium columnare: evaluation of humoral immune response by ELISA and in vivo efficiency in Nile tilapia (Oreochromis niloticus). Aquacult Int (2010) 18(4):657-66. doi:10.1007/s10499-009-9287-x

68. de las Heras AI, Rodriguez Saint-Jean S, Perez-Prieto SI. Immunogenic and protective effects of an oral DNA vaccine against infectious pancreatic necrosis virus in fish. Fish Shellfish Immunol (2010) 28(4):562-70. doi:10.1016/j. fsi.2009.12.006

69. Ballesteros NA, Saint-Jean SS, Encinas PA, Perez-Prieto SI, Coll JM. Oral immunization of rainbow trout to infectious pancreatic necrosis virus (Ipnv) induces different immune gene expression profiles in head kidney and pyloric ceca. Fish Shellfish Immunol (2012) 33(2):174-85. doi:10.1016/j.fsi.2012.03.016

70. Ballesteros NA, Saint-Jean SS, Perez-Prieto SI, Coll JM. Trout oral VP2 DNA vaccination mimics transcriptional responses occurring after infection with infectious pancreatic necrosis virus (IPNV). Fish Shellfish Immunol (2012) 33(6):1249-57. doi:10.1016/j.fsi.2012.09.004

71. Rajesh KS, Ishaq Ahmed VP, Parameswaran V, Sudhakaran R, Sarath BV, Sahul Hameed AS. Potential use of chitosan nanoparticles for oral delivery of DNA vaccine in Asian sea bass (Lates calcarifer) to protect from Vibrio (Listonella) anguillarum. Fish Shellfish Immunol (2008) 25(1-2):47-56. doi:10.1016/j.fsi.2007.12.004

72. Adomako M, St-Hilaire S, Zheng Y, Eley J, Marcum RD, Sealey W, et al. Oral DNA vaccination of rainbow trout, Oncorhynchus mykiss (Walbaum), against infectious haematopoietic necrosis virus using PLGA [Poly(D,LLactic-Co-Glycolic Acid)] nanoparticles. J Fish Dis (2012) 35(3):203-14. doi:10.1111/j.1365-2761.2011.01338.x

73. Tian J, Yu J. Poly(lactic-co-glycolic acid) nanoparticles as candidate DNA vaccine carrier for oral immunization of Japanese flounder (Paralichthys olivaceus) against lymphocystis disease virus. Fish Shellfish Immunol (2011) 30(1):109-17. doi:10.1016/j.fsi.2010.09.016

74. Rivas-Aravena A, Fuentes Y, Cartagena J, Brito T, Poggio V, La Torre J, et al. Development of a nanoparticle-based oral vaccine for Atlantic salmon against ISAV using an alphavirus replicon as adjuvant. Fish Shellfish Immunol (2015) 45(1):157-66. doi:10.1016/j.fsi.2015.03.033

75. Costerton JW, Geesey GG, Cheng KJ. How bacteria stick. Sci Am (1978) 238:86-95. doi:10.1038/scientificamerican0178-86

76. Donlan RM, Costerton JW. Biofilms: survival mechanisms of clinically relevant microorganisms. Clin Microbiol Rev (2002) 15(2):167-93. doi:10.1128/ CMR.15.2.167-193.2002

77. Azad IS, Shankar KM, Mohan CV, Kalita B. Uptake and processing of biofilm and free-cell vaccines of Aeromonas hydrophila in Indian major carps and common carp following oral vaccination - antigen localization by a monoclonal antibody. Dis Aquat Organ (2000) 43(2):103-8. doi:10.3354/dao043103

78. van Stappen G. Introduction, biology and ecology of Artemia. In: Lavens P, Sorgeloos P, editors. Manual on the Production and Use of Live Food for Aquaculture. Rome: FAO (1996). p. 79-250.

79. Scholz T. Parasites in cultured and feral fish. Vet Parasitol (1999) 84(3-4):31735. doi:10.1016/S0304-4017(99)00039-4

80. Canty MN, Hagger JA, Moore RT, Cooper L, Galloway TS. Sublethal impact of short term exposure to the organophosphate pesticide azamethiphos in the marine mollusc Mytilus edulis. Mar Pollut Bull (2007) 54(4):396-402. doi:10.1016/j.marpolbul.2006.11.013

81. MacKinnon BM. Sea Lice: a Review: World Aquaculture. (Vol. 28). (1997). p. $5-10$.

82. Kaur K, Helgesen KO, Bakke MJ, Horsberg TE. Mechanism behind resistance against the organophosphate azamethiphos in Salmon lice (Lepeophtheirus salmonis). PLoS One (2015) 10(4):e0124220. doi:10.1371/journal.pone.0124220 
83. McNair CM. Ectoparasites of medical and veterinary importance: drug resistance and the need for alternative control methods. J Pharm Pharmacol (2015) 67(3):351-63. doi:10.1111/jphp.12368

84. Findlay VL, Helders BL, Munday BL, Gurney R. Demonstration of resistance to reinfection with Paramoeba sp. by Atlantic salmon, Salmo salar L. J Fish Dis (2006) 18(6):639-42. doi:10.1111/j.1365-2761.1995.tb00370.x

85. Adams MB, Crosbie PB, Nowak BF. Preliminary success using hydrogen peroxide to treat Atlantic salmon, Salmo salar L., affected with experimentally induced amoebic gill disease (AGD). J Fish Dis (2012) 35(11):839-48. doi:10.1111/j.1365-2761.2012.01422.x

86. Lotter H, Russmann H, Heesemann J, Tannich E. Oral vaccination with recombinant Yersinia enterocolitica expressing hybrid type III proteins protects gerbils from amebic liver abscess. Infect Immun (2004) 72(12):7318-21. doi:10.1128/IAI.72.12.7318-7321.2004

87. Lotter H, Russmann H, Heesemann J, Tannich E. Attenuated recombinant Yersinia as live oral vaccine carrier to protect against amoebiasis. Int J Med Microbiol (2008) 298(1-2):79-86. doi:10.1016/j.ijmm.2007.07.001

88. Salinas I, Lapatra SE, Erhardt EB. Nasal vaccination of young rainbow trout (Oncorhynchus mykiss) against infectious hematopoietic necrosis and enteric red mouth disease. Dev Comp Immunol (2015) 53(1):105-11. doi:10.1016/j. dci.2015.05.015

89. Galindo-Villegas J, Mulero I, Garcia-Alcazar A, Munoz I, Penalver-Mellado M, Streitenberger S, et al. Recombinant TNFalpha as oral vaccine adjuvant protects European sea bass against vibriosis: insights into the role of the CCL25/CCR9 axis. Fish Shellfish Immunol (2013) 35(4):1260-71. doi:10.1016/j.fsi.2013.07.046

90. Biering E, Salonius K. DNA vaccines. In: Gudding R, Lillehaug A, Evensen $\emptyset$, editors. Fish Vaccination. Oxford: Wiley Blackewell (2014). p. 47-55.

Conflict of Interest Statement: The authors declare that the research was conducted in the absence of any commercial or financial relationships that could be construed as a potential conflict of interest.

Copyright (c) 2015 Mutoloki, Munang'andu and Evensen. This is an open-access article distributed under the terms of the Creative Commons Attribution License (CC $B Y)$. The use, distribution or reproduction in other forums is permitted, provided the original author(s) or licensor are credited and that the original publication in this journal is cited, in accordance with accepted academic practice. No use, distribution or reproduction is permitted which does not comply with these terms. 